\title{
Morphology and ultrastructure of the midgut in Piscicola geometra (Annelida, Hirudinea)
}

\author{
Magdalena M. Rost-Roszkowska • Piotr Świątek • \\ Michalina Kszuk • Kinga Glówczyk • \\ Aleksander Bielecki
}

Received: 1 July 2011 / Accepted: 5 October 2011 /Published online: 21 October 2011

(C) The Author(s) 2011. This article is published with open access at Springerlink.com

\begin{abstract}
This paper presents information on the organization of the midgut and its epithelium ultrastructure in juvenile and adult specimens of Piscicola geometra (Annelida, Hirudinea), a species which is a widespread ectoparasite found on the body and gills and in the mouth of many types of fish. The analysis of juvenile nonfeeding specimens helped in the explanation of all alterations in the midgut epithelium which are connected with digestion. The endodermal portion (midgut) of the digestive system is composed of four regions: the esophagus, the crop, the posterior crop caecum, and the intestine. Their epithelia are formed by flat, cuboidal, or columnar digestive cells; however, single small cells which do not contact the midgut lumen were also observed. The ultrastructure of all of the regions of the midgut are described and discussed with a special emphasis on their functions in the digestion of blood. In P. geometra, the part of the midgut that is devoid of microvilli is responsible for the accumulation of blood, while the epithelium of the remaining part of the midgut, which has a distinct regionalization in the distribution of
\end{abstract}

\section{Handling Editor: Pavel Dráber}

M. M. Rost-Roszkowska $(\bowtie) \cdot$ P. Świątek $\cdot$ M. Kszuk •

K. Główczyk

Department of Animal Histology and Embryology,

University of Silesia,

Bankowa 9,

40-007 Katowice, Poland

e-mail: magdalena.rost-roszkowska@us.edu.pl

P. Świątek

e-mail: piotr.swiatek@us.edu.pl

\author{
A. Bielecki \\ Department of Zoology, University of Warmia and Mazury, \\ Oczapowskiego 5, \\ 10-967 Olsztyn-Kortowo, Poland \\ e-mail: alekb@uwm.edu.pl
}

organelles, plays a role in its absorption and secretion. Glycogen granules in the intestinal epithelium indicate its role in the accumulation of sugar. The comparison of the ultrastructure of midgut epithelium in juvenile and adult specimens suggests that electron-dense granules observed in the apical cytoplasm of digestive cells take part in enzyme accumulation. Numerous microorganisms were observed in the mycetome, which is composed of two large oval diverticles that connect with the esophagus via thin ducts. Similar microorganisms also occurred in the cytoplasm of the epithelium in the esophagus, the crop, the intestine, and in their lumen. Microorganisms were observed both in fed adult and unfed juvenile specimens of $P$. geometra, which strongly suggests that vertical transmission occurs from parent to offspring.

Keywords Leeches · Midgut epithelium · Digestive system $\cdot$ Haem digestion $\cdot$ Endosymbionts

\section{Introduction}

The digestive tract of invertebrates is composed of three distinct regions: the foregut, the midgut, and the hindgut. While the foregut and hindgut are of an ectodermal origin, the midgut is formed by the endoderm and is responsible for absorption, enzyme secretion, storage of toxic substances (e.g., excessive metals), and even for excretion when there are no excretory organs. It is also the first barrier against any invasion of pathogens because it takes part in homeostatic maintenance. Depending on its different functions and the kinds of food consumed, the midgut may possess a tube-like shape, numerous caeca, or it may be differentiated into distinct regions (Saulnier-Michel 
1992; Silva et al. 2006; Rost-Roszkowska et al. 2010a, b, 2011). Its digestive functions might additionally be delivered by symbiotic microorganisms which supply digestive enzymes, amino acids, fatty acids, or help in the detoxification and neutralization of toxic substances (Nakabachi and Ishikawa 1999; Baumann 2005; Graf et al. 2006).

Among Annelida, Polychaeta, and Oligochaeta sensu stricto are the groups for which the midgut epithelia are well known (Jamieson 1981; Punin and Lukyanova 1984; Saulnier-Michel 1992; Jenkins et al. 2002), although the ultrastructure of the digestive cells in the midgut of Hirudinea has been analyzed only in four species: Hirudo medicinalis (Hirudinidae), Haementeria depressa, Helobdella triserialis, and Theromyzon rude (Glossiphoniidae) (Hammersen and Pokahr 1972a, b; Fernádez et al. 1992). It is also known that species which belong to Rhynchobdellida possess the bacterial symbiont-containing organ called a mycetome that is connected to the esophagus, while it is absent in Arhynchobdellida, where symbionts settle in the epithelium of the digestive tract (Siddall et al. 2004; Perkins et al. 2005; Graf et al. 2006). Many species of leeches are ectoparasites of invertebrates and vertebrates in which they cause diseases and have negative effects on those animals that are commercially raised. A precise description of their midgut epithelium at the ultrastructural level would help in controlling the pests that belong to Hirudinea.

Piscicola geometra is a widespread ectoparasite found on the body and gills and in the mouth of many fish, e.g., salmon (Salmo salar), brown trout (Salmo trutta), charr (Salvelinus alpinus), bream (Abramis brama), gudgeon (Gobio gobio), European eel (Anguilla anguilla), perch (Perca fluviatilis), gibel carp (Carassius gibelio), and common carp (Cyprinus carpio) (Bielecki 1997; Arslan and Emiroğlu 2011). P. geometra uses its proboscis to penetrate a host's tissues and suck its blood. When it is not attached to the body of a host, it can be found freeliving, on and beneath stones and macrophytes. This paper presents the first part of our results connected with the organization of the midgut and its epithelial ultrastructure in juvenile and adult specimens of $P$. geometra. The aims of this study were: (a) to describe the ultrastructure of the endodermal part of the digestive tract (midgut) of the fish leech, P. geometra (Piscicolidae), as a representative of Rhynchobdellida; (b) to describe any differences in the distribution of organelles in juvenile nonfeeding and adult feeding specimens; and (c) to determine whether symbionts colonize both the mycetome and the midgut epithelium. Analysis of juvenile nonfeeding specimens was used in order to explain all alterations in the midgut epithelium which appear after blood meal.

\section{Material and methods}

Material

Specimens of $P$. geometra (Linnaeus, 1758) were used in the research. Sexually mature specimens were collected from $C$. carpio and then bred under laboratory conditions. Mature specimens were fed on Danio rerio. Juveniles were collected immediately after hatching from a cocoon. Four juveniles and about 30 adult specimens were collected, fixed, and studied with the use of light and electron microscopy techniques.

Light and electron microscopy

The specimens studied were prepared and fixed in the same manner as in the case of previously studied clitellate annelids (Świątek et al. 2011). Briefly, they were initially fixed with $2.5 \%$ glutaraldehyde in a $0.1 \mathrm{M}$ sodium phosphate buffer (pH 7.4). Their bodies were then divided into smaller pieces and fixed in $2.5 \%$ glutaraldehyde in the same buffer at room temperature for 2 days. After washing in a sodium phosphate buffer, the material was postfixed for $2 \mathrm{~h}$ in $1 \% \mathrm{OsO}_{4}$ in the same buffer, dehydrated in a graded series of ethanol replaced by acetone, and then embedded in an Epoxy Embedding Medium Kit (Sigma, St. Louis, MO). Semithin sections (0.8$\mu \mathrm{m}$ thick) stained with methylene blue were examined under an Olympus BX60 microscope equipped with a DP12 digital camera and AnaliSIS 3.2 (Soft Imaging System) software. Ultrathin sections $(80 \mathrm{~nm})$ were cut on a Leica ultracut UCT ultramicrotome. After contrasting with uranyl acetate and lead citrate, the sections were examined using a Hitachi H500 electron microscope at $75 \mathrm{kV}$. In addition, several mature specimens were first anesthetized in $10 \%$ ethanol, then rinsed of any mucus in 50\% ethanol, and finally placed in test tubes with $75 \%$ ethanol or a $3 \%$ aqueous solution of formalin. These leeches were then dissected and photographed using an Olympus SZ-ST stereomicroscope.

\section{Results}

The endodermal part of the digestive tract in P. geometra, both in nonfeeding juveniles and adult specimens, is composed of four regions: the esophagus, the crop, the posterior crop caecum, and the intestine (Fig. 1). The endodermal epithelium is formed by a single layer of cuboidal cells which rest on the noncellular basal lamina. The midgut epithelium is surrounded by two layers of visceral muscles: the inner circular and the outer longitudinal fibers. The following description concerns both juvenile nonfeeding and adult feeding specimens of $P$. geometra, except in areas where differences between the two stages are noted. 
Ultrastructure of the esophagus and crop in P. geometra

The esophagus is the first endodermal region of the digestive tract of $P$. geometra and it has a tube-like shape (Fig. 1). The crop (Fig. 1) is composed of seven splanchnomeres which spread from the XII/XIII to XIX/ $\mathrm{XX}$ somites of the body. Each splanchnomere is divided pair-wise along the right and left margin forming lateral diverticles, which are secondarily divided into the blind-end caeca (Fig. 2). Only the first splanchnomere differs from the others because its diverticles are not secondarily divided but form long caeca which elongate toward the second splanchnomere (Figs. 1 and 2).

The epithelium of the esophagus and the first splanchnomere of the crop are composed of flat epithelial cells, whose basal membrane does not form any folds and whose apical membrane does not form microvilli (first splanchnomere) or where the short microvilli are irregularly distributed (esophagus) (Figs. 3 and 4). It should be strengthened here that the cuticle which covers the esophagus epithelium has been never observed. The cytoplasm is poor in mitochondria and
Figs. 1-4 1 Schematic illustration of the digestive tract organization in P. geometra. After Bielecki (1997) modified. 2

Adult specimen prepared along the dorsal midline. The crop is composed of splanchnomeres, 1st $s p$ - the first splanchnomere of the crop, $s p$ - splanchnomeres with lateral diverticles (arrows - the borders between the diverticles were artificially marked), the artificial cleft between the first splanchnomere and next one is visible (star). Body wall $(b w)$. Stereomicroscope (SM), bar $=200 \mu \mathrm{m} .3$ The esophagus in adult specimens of $P$. geometra. Microorganisms $(b)$, basal lamina $(b l)$, midgut lumen $(l)$, microvilli $(m v)$, and zonulae adherens $(z a)$. Transmission electron microscopy (TEM), bar $=1 \mu \mathrm{m}$. 4 First splanchnomere of the crop in adult specimens of $P$. geometra. The cytoplasm with mitochondria $(m)$ and cisterns of rough endoplasmic reticulum (RER). Basal lamina $(b l)$, midgut lumen (l). TEM, bar $=0.7 \mu \mathrm{m}$

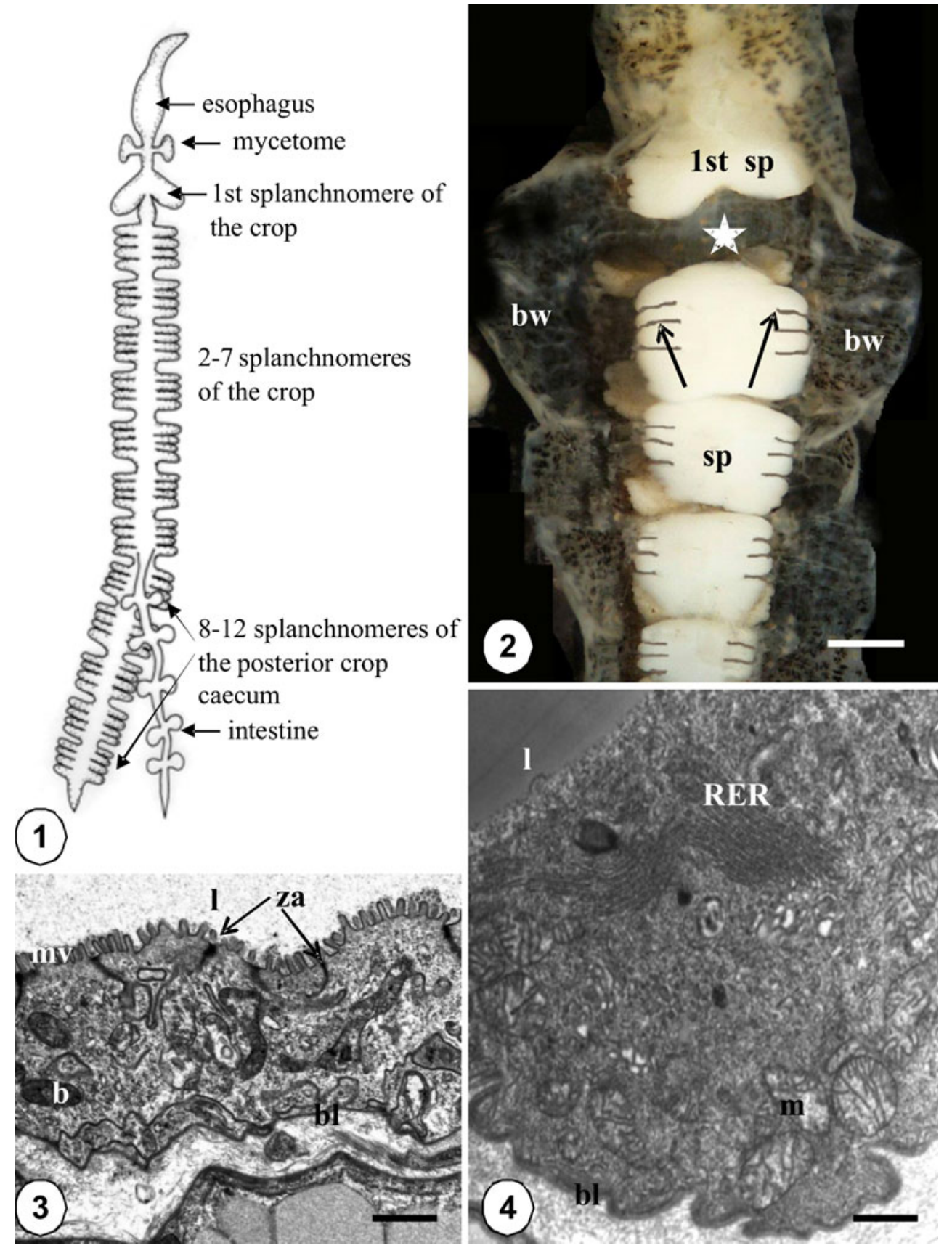


possesses cisterns of rough endoplasmic reticulum (Fig. 4). Zonulae adherens as the distinct intercellular junctions appeared between adjacent epithelial cells (Fig. 3).

The epithelium of the remaining six splanchnomeres in the crop (Fig. 5) is composed of digestive cells which, depending on the presence of food in the midgut lumen, become cuboidal (Fig. 6) or columnar in shape. Single and sparsely distributed small cells were observed between the basal regions of the digestive cells (Fig. 7).

The digestive cells show distinct regionalization in the distribution of organelles: basal, perinuclear, and apical
Figs. 5-9 5 Longitudinal section through the adult leech body. Within the sectioned diverticles $(l)$, host blood cells (arrow) are visible. Midgut epithelium $(e)$, muscles $(m)$, testes $(t)$. Light microscopy (LM), bar $=45 \mu \mathrm{m}$. 6 Adult specimen in a cross-section. The epithelium of the crop splanchnomeres with the digestive cells (e). Midgut lumen $(l)$. TEM, bar $=2.8 \mu \mathrm{m} .7$ Adult specimen. Small cells $(s c)$ between the basal regions of the digestive cells $(e)$. Basal lamina $(b l)$, microvilli $(m v)$, nucleus $(n)$. TEM, $b a r=0.6 \mu \mathrm{m} .8$ Adult specimen of $P$. geometra. Folds of the basal membrane (arrowheads), basal lamina (arrow), mitochondria $(m)$, nucleus $(n)$, electron-dense vesicles (star), Golgi complexes $(d)$, and visceral muscles $(\mathrm{vm})$. TEM, $b a r=0.5 \mu \mathrm{m} .9$ Digestive cell in the crop of adult specimen of P. geometra. Vesicles with an electron-dense content (star), cisterns of RER (RER), Golgi complexes $(d)$, nucleus $(n)$, midgut lumen $(l)$, microvilli $(m v)$, and microorganism (arrow). TEM, bar $=0.4 \mu \mathrm{m}$
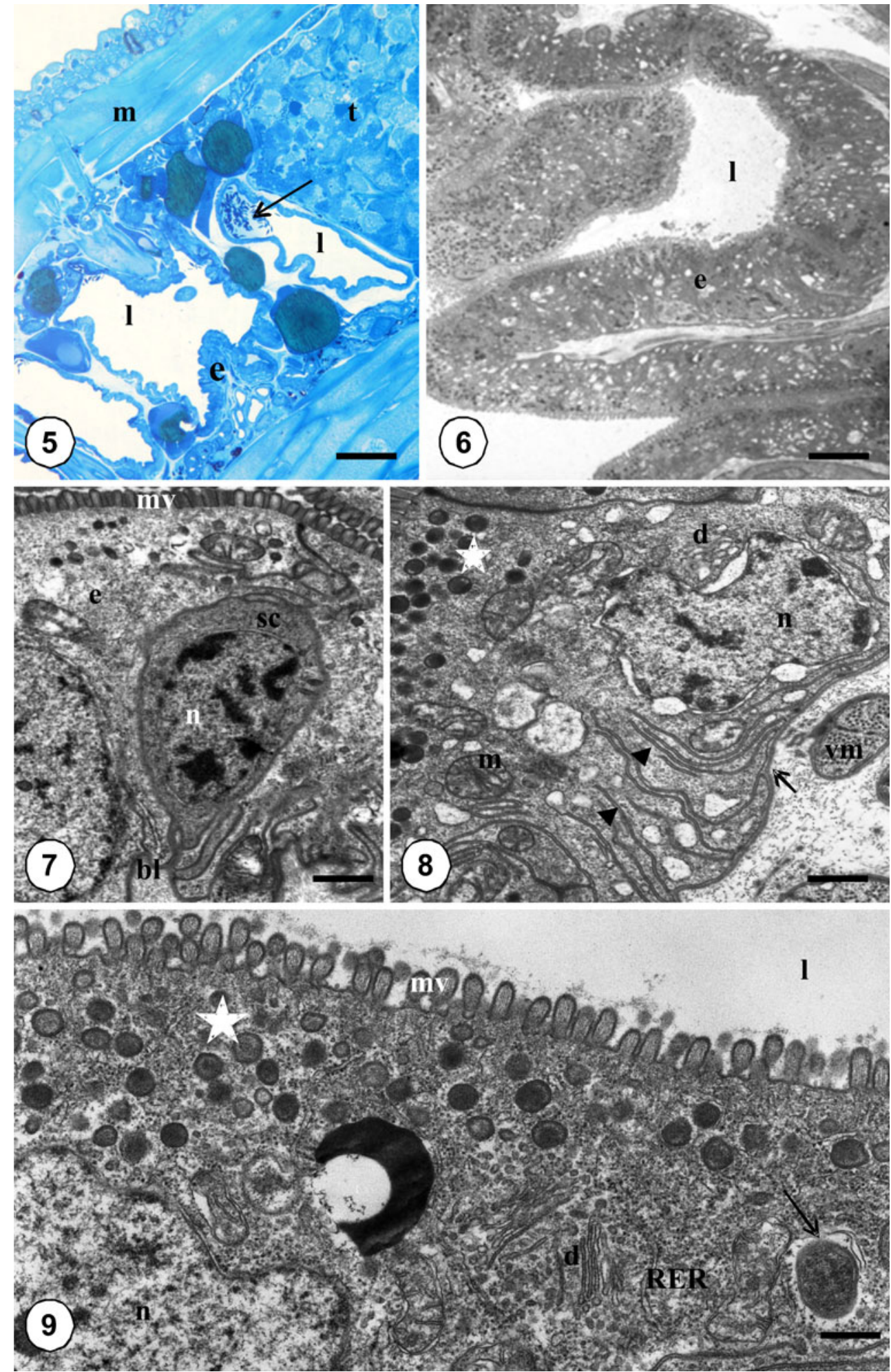
regions can be distinguished (Fig. 8). The basal membrane forms small folds which might enter the perinuclear region. Large mitochondria with sporadic cristae and vacuoles accumulate near the basal membrane folds (Fig. 8). The nucleus, which might be shifted into the basal cytoplasm (Fig. 8), possesses only a small concentration of heterochromatin and a large distinct nucleolus. Golgi complexes and cisterns of rough endoplasmic reticulum concentrate near the nucleus (Figs. 8 and 9). The apical cytoplasm of the digestive cells found in adult specimens is rich in small vesicles with an electron-dense content (Figs. 8 and 9). However, those vesicles are also observed in the cytoplasm of juveniles specimens that do not feed, although their content is less electron dense (Fig. 10) than that of adults (Fig. 9). The apical membrane forms short microvilli. The entire cytoplasm is rich in free ribosomes. Sporadic lipid droplets and large autolysosomes may also occur in their cytoplasm. Intercellular junctions such as zonula adherens in the apical region and septate junctions in the perinuclear and basal regions appear between adjacent digestive cells (Fig. 11).

The cytoplasm of small cells is more electron dense than that of the digestive cells and is poor in organelles (Fig. 7) such as cisterns of rough endoplasmic reticulum and mitochondria. The chromatin is densely packed near the nuclear envelope. As these small cells do not contact the midgut lumen, their apical membranes do not form microvilli. Neither storage material (electron dense granules) nor secretory vesicles are observed in their cytoplasm.

Ultrastructure of the posterior crop caecum in $P$. geometra

The posterior crop caecum (PCC) represents a blind-end structure located ventrally to the intestine (Figs. 1, 12, and 13). This structure is formed by five splanchnomeres (Figs. 1 and 12) which spread from the $\mathrm{XX} / \mathrm{XXI}$ to $\mathrm{XXV} / \mathrm{XXVI}$ somites. Each splanchnomere is divided into blind-ended lateral diverticles (Fig. 12).

The PCC epithelium is composed of cuboidal epithelial cells in nonfeeding specimens (Fig. 13), which are extremely elongated and flat when the gut is filled with the host blood (Fig. 14) and rarely distributed small cells (not shown). The regionalization in the distribution of organelles in the cytoplasm of the epithelial cells is evidently similar to the crop (Fig. 15). The basal membrane forms small and sporadic folds, whereas the apical membrane forms abundant microvilli (Fig. 15). Large mitochondria with small cristae and an electron-lucent matrix (possibly an effect of the fixation) accumulate mainly in the basal cytoplasm, while the apical cytoplasm is rich in numerous vesicles with an electron-dense content (Fig. 15). Those vesicles possess less electron-dense content in juvenile nonfeeding specimens (not shown). Numerous cisterns of rough and smooth endoplas- mic reticulum and Golgi complexes accumulate in the central part of the cytoplasm, between the electron-dense vesicles of the apical cytoplasm and near the lateral cell membranes (Fig. 15). The nucleus possesses a large nucleolus and small patches of heterochromatin (not shown). The entire cytoplasm is rich in free ribosomes. Zonula adherens and septate junctions are observed between adjacent epithelial cells (not shown).

\section{Ultrastructure of the intestine in P. geometra}

The intestine of analyzed specimens is located dorsally to the PCC and is connected to the hindgut (Figs. 1 and 12). It begins at the end of the seventh splanchnomere of the crop (somite $\mathrm{XIX} / \mathrm{XX}$ ) and possesses five blind-end caeca (Fig. 12).

The intestinal epithelium is formed by columnar cells (Figs. 13 and 16) whose cytoplasm possesses distinct basal, perinuclear, and apical regions (Fig. 16). The basal membrane forms numerous folds which are accompanied by mitochondria (Fig. 16); however, these folds are not so evident in young specimens (not shown). Golgi complexes and cisterns of rough endoplasmic reticulum are distributed in the area near the nucleus, while the apical cytoplasm is rather poor in organelles such as mitochondria and small cisterns of rough endoplasmic reticulum (Fig. 17). The apical membrane forms short, but numerous microvilli (Fig. 17). In several adult specimens, the midgut epithelium is separated from the midgut lumen by a thin membranous structure (Figs. 16 and 17). The entire cytoplasm is rich in free ribosomes, while glycogen granules accumulate in the cytoplasm of midgut cells only in some specimens (Fig. 18). Adjacent epithelial cells are connected via zonula adherens junctions (Fig. 17). Vesicles with an electrondense content, which are common for the epithelial cells of the crop and posterior crop caeca, are absent (Figs. 16-18). The second type of cells, called small cells, which appear between epithelial cells but do not contact the midgut lumen, are not observed in intestinal region of the midgut.

\section{Endosymbionts in the midgut of $P$. geometra}

Numerous microorganisms are observed both in the mycetome and in the cells of the midgut epithelium. The mycetome is composed of two large oval diverticles which connect to the esophagus via thin ducts (Figs. 1, 19, and 20). It is located in the XII/XIII body somite between the fourth and fifth neural ganglia. Microorganisms accumulate in the mycetome lumen (Figs. 20 and 21) and are also located in the cytoplasm of the epithelium in the esophagus, the crop, and the intestine (Figs. 9, 15, 22, and 23). They are observed both in the fed adult and unfed juvenile specimens. 
Figs. 10-14 10 Juvenile specimen. Digestive cell of the crop with single vesicles with electron-dense content (star). Cisterns of RER (RER), Golgi complexes $(d)$, mitochondrium $(m)$, microvilli $(m v)$, and nucleus (n). TEM, bar $=0.4 \mu \mathrm{m}$. 11 The crop in adult specimen. Zonula adherens $(z a)$ in the apical region and septate junction $(s j)$ in the perinuclear region of the digestive cell cytoplasm. Microvilli $(m v)$, mitochondrium $(m)$. TEM, $b a r=0.15 \mu \mathrm{m}$. 12 The postclitellar and posterior parts of the adult specimen body prepared along the dorsal midline. Splanchnomeres of the posterior crop caecum (PCC) spread perpendicular to the intestine $(i)$. Blind-end caeca of intestine (arrowheads), body wall $(b w)$, hindgut $(h g)$, anus (arrow). SM, bar $=500 \mu \mathrm{m} .13$ Juvenile specimen. The epithelium (arrow) of the posterior crop caecum $(P C C)$. The epithelium of the intestine $(e)$, midgut lumen $(l)$, nerve cord $(n c)$, body wall $(b w)$. LM, bar $=50 \mu \mathrm{m} .14$ Adult specimen. The PCC is filled with blood and its epithelium is thin and strongly extended (arrow). Intestine epithelium $(e)$ and lumen $(l)$. Body wall $(b w)$. LM, bar $=30 \mu \mathrm{m}$
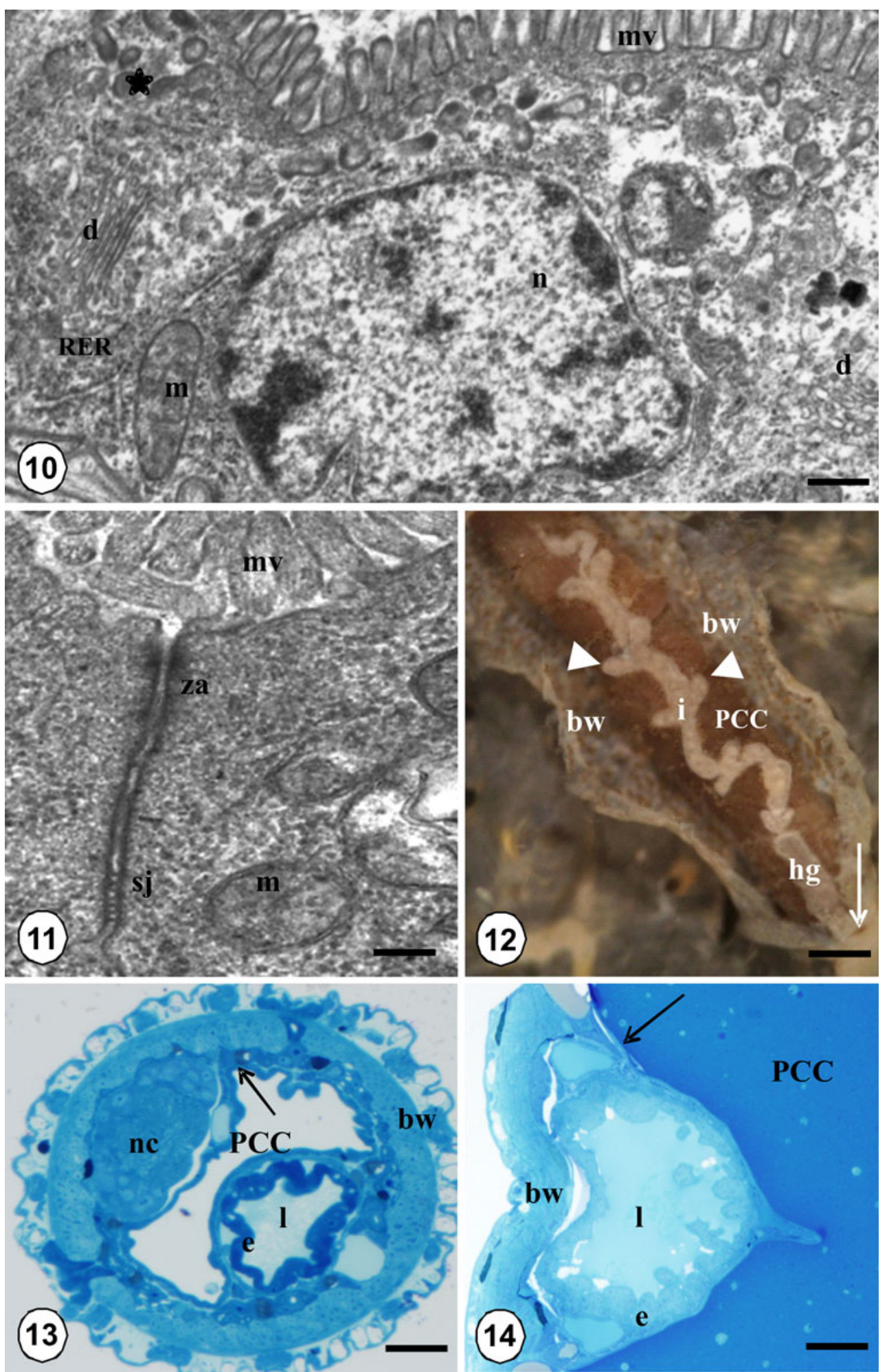

\section{Discussion}

Polychaeta and Oligochaeta sensu stricto are the annelid groups that have been primarily analyzed with a special emphasis on the midgut epithelium (Jamieson 1981, 1992; Saulnier-Michel 1992), whereas data are rather poor for
Hirudinea. In these latter blood-feeding annelids, the midgut is divided into some regions with many blind-end caeca, while its corresponding structure in predators is much simpler (Jamieson 1981; Punin et al. 2000; Jenkins et al. 2002).

The foregut and the hindgut, which are of an ectodermal origin, are covered by a cuticle, which the endodermal 
Figs. 15-18 15 The PCC epithelium in adult specimen of $P$. geometra. Basal lamina $(b l)$, electron dense vesicles (star), microvilli $(m v)$, mitochondria $(m)$, cisterns of RER $(R E R)$, Golgi complexes $(d)$, microorganisms (arrows), and midgut lumen $(l)$. TEM, bar $=0.5 \mu \mathrm{m}$. 16-18 Adult specimen. The intestine epithelium $(e)$ is formed by columnar, digestive cells. A thin membranous structure (arrow) visible on the surface of the microvilli $(m v)$. Glycogen granules $(g)$, midgut lumen $(l)$, cisterns of RER (RER), zonula adherens $(z a)$. TEM, bar $=$ $3.3 \mu \mathrm{m}$ in Fig. 16, bar $=0.4 \mu \mathrm{m}$ in Fig. 17, bar $=0.8 \mu \mathrm{m}$ in Fig. 18

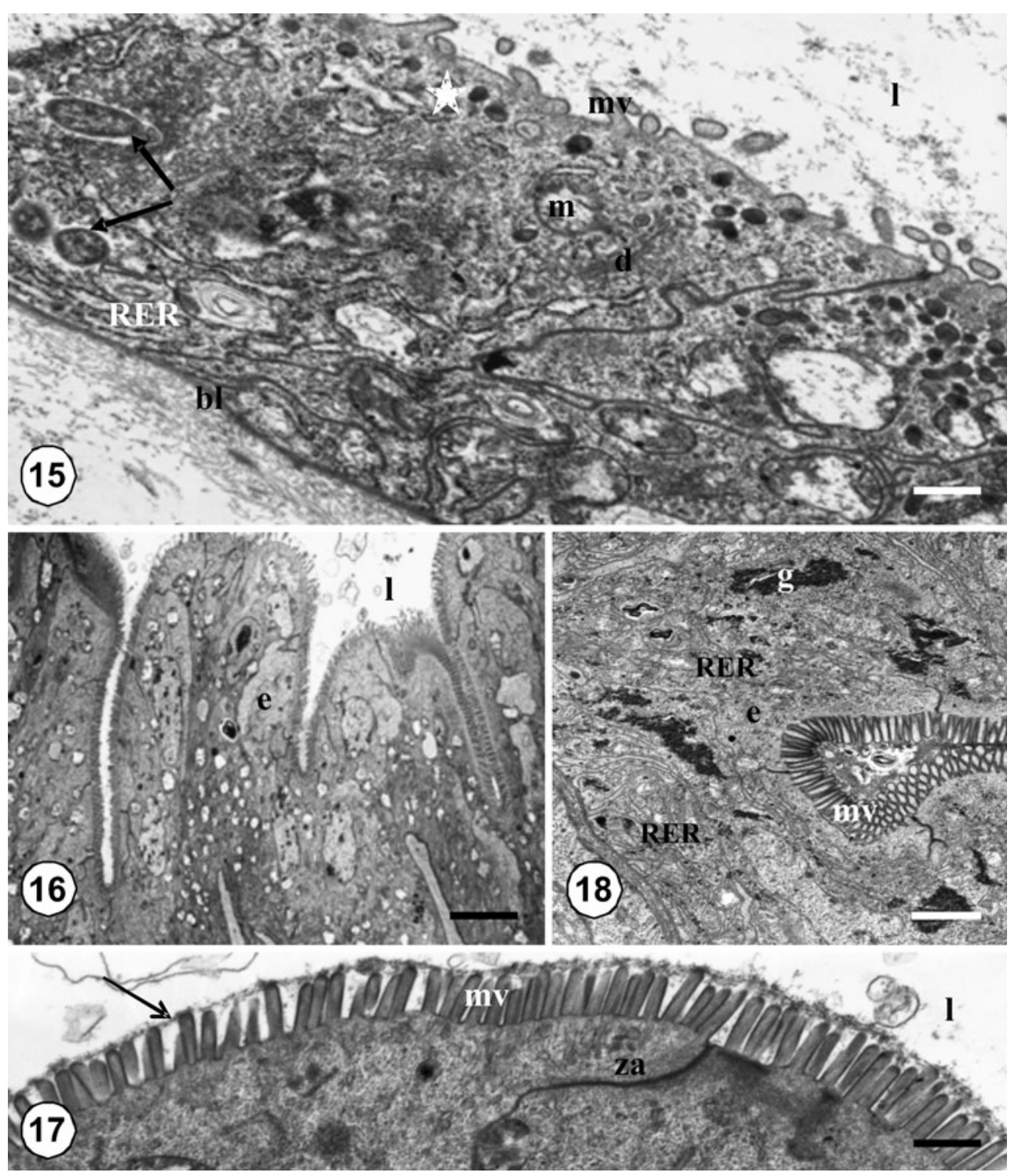

midgut lacks (Fernádez et al. 1992). In P. geometra, the four regions of the digestive system lack the cuticle and possess the microvilli: the esophagus, the crop, the posterior crop caecum, and the intestine. The esophagus is the phenomenon because in annelids it is treated as the part of ectodermal foregut (Badham 1916; Fernádez et al. 1992; Perkins et al. 2005), while in P. geometra it does not resemble the typical ectodermal epithelium, e.g., it lacks cuticle. The localization of this part of the digestive tract between proboscis and crop suggests that it is the esophagus, as it was described for the other leeches (Fernádez et al. 1992). We suppose that in Piscicolidae, mycetomes do not contact the ectodermal region of the digestive system but contact its endodermal part, therefore the region called as "esophagus" would be the first part of the midgut. Data connected with the embryogenesis of Hirudinida revealed that pharynx and proboscis are of ectodermal origin, while endodermal midgut is composed of the crop and the intestine (Siddall et al. 2006). However the problem of esophagus origin has not been resolved distinctly (Siddall et al. 2006). According to our results, we suggest that the esophagus of $P$. geometra may be an endodermal part of the digestive system, but it should be confirmed by the analysis of embryogenesis.

The midgut is much more differentiated in blood-feeding invertebrates such as insects, than in predators. Though distinct regionalization in functions has been described in the midgut of blood-feeding Hemiptera (Billingsley 1988; Azevedo et al. 2009), there are no striking differences between all of the regions of the midgut in P. geometra, despite the different structure of the esophagus and the first splanchnomere of the crop. In Rhodnius prolixus, the anterior midgut/crop is the site of water transport and of lipid and glycogen storage. The anterior intestine is the site of most proteinase synthesis and secretion, while the posterior intestine is responsible for some secretory activity, 
Figs. 19-23 19 Adult specimen. Mycetomes $(m c)$ are composed of two large oval diverticles which connect to the esophagus (es) via thin ducts (arrow). SM, bar $=250 \mu \mathrm{m} .20$ Adult specimen of $P$. geometra. Body wall (bw), esophagus (es), mycetomes $(m c)$, nerve cord (nc). LM, bar $=45 \mu \mathrm{m}$. 21 Adult specimen. Microorganisms (arrows) accumulate in the mycetome lumen $(\mathrm{ml})$. Basal lamina $(b l)$, microvilli $(m v)$, mycetome epithelium (me), visceral muscles $(\mathrm{vm})$. TEM, bar $=1.7 \mu \mathrm{m} .22-23$ Adult specimen. Microorganisms (arrows) in the cytoplasm of the midgut epithelium in the first splanchnomere of the crop (22) and in the one of the remaining splanchnomeres of the crop (23). Midgut lumen $(l)$, microvilli $(m v)$, basal lamina (bl). TEM, bar $=0.34 \mu \mathrm{m}$ in (22), bar $=0.5 \mu \mathrm{m}$ in Fig. 23
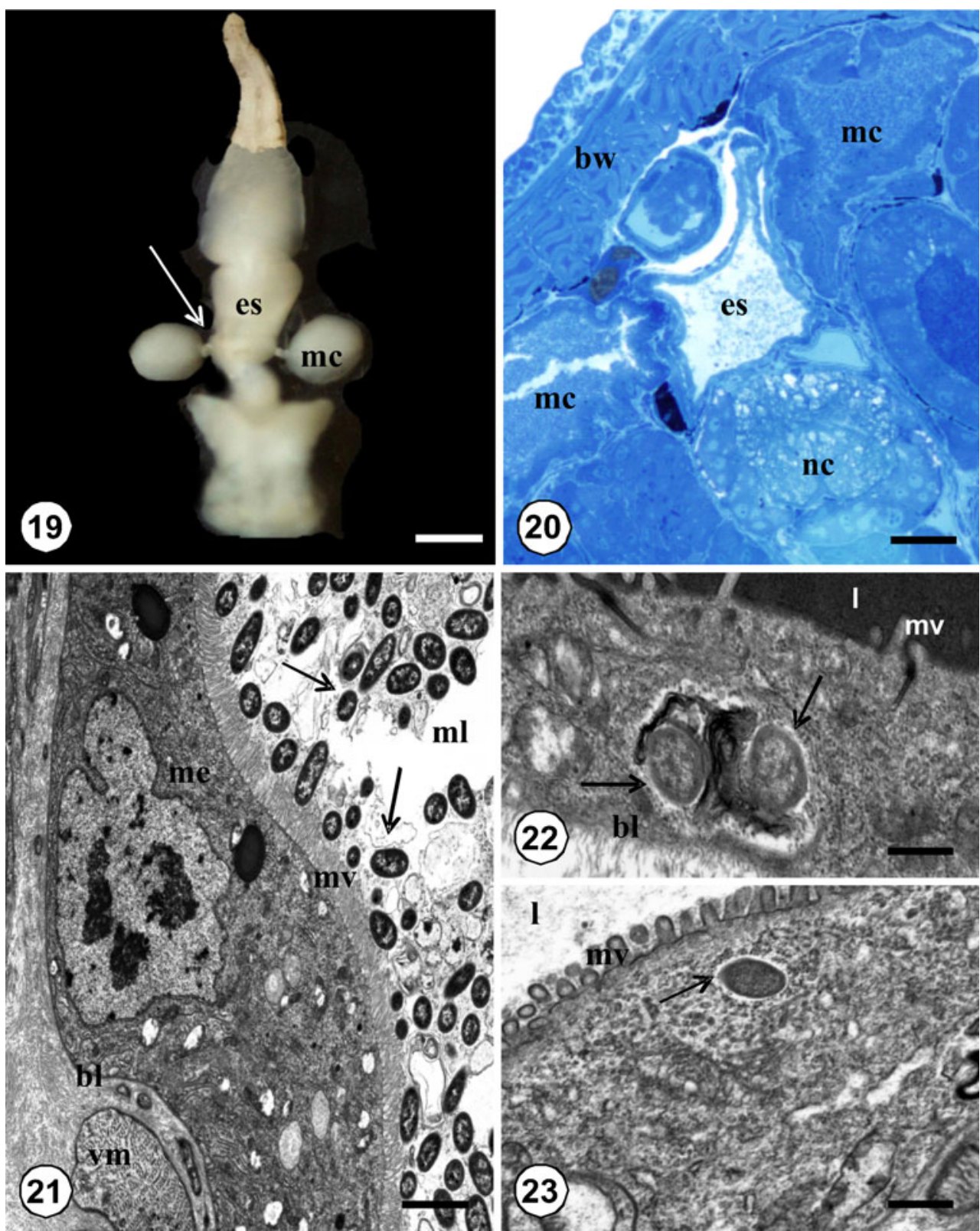

the absorption of digested nutrients, and the absorption and storage of carbohydrates (Billingsley 1988). In Cimex hemipterus, the anterior midgut is responsible for water absorption, ion regulation, digestion, and storage of lipids and sugars; the middle midgut is active in digestive processes, and the posterior midgut takes part in nutrient absorption (Azevedo et al. 2009). In P. geometra, the part of the midgut which is devoid of microvilli is responsible for the accumulation of water or fluid from the blood, while the entire epithelium of the remaining part of the midgut plays a role in absorption and secretion. Glycogen granules in the intestinal epithelium indicate its role in the accumulation of sugar.

In Polychaeta and Oligochaeta sensu stricto, the midgut epithelium is formed by different types of cells: endocrine cells, microvillar cells, and ciliated cells (Jamieson 1981, 1992; Saulnier-Michel 1992; Jenkins et al. 2002). Among Hirudinea, ultrastructural studies were related to the midgut epithelium of $H$. medicinalis, $H$. depressa, $H$. triserialis, and T. rude (Hammersen and Pokahr 1972a, b; Fernádez et al. 1992) where digestive cells are adapted to secretion and absorption. Punin et al. (2000), using immunocytochemical methods, showed the regulatory activity of several cells of the midgut epithelium in Glossiphonia complanata, $H$. medicinalis, Erpobdella octoculata, and Haemopis sanguisuga. Those cells are FRMF-amide-, serotonin-, calcitonine-, and neurotensin-positive, so they fulfill the role of endocrine cells. Some of them are of a closed type because they do not contact the midgut lumen, while the rest reach the midgut surface by long protrusions. In the 
authors' studies on P. geometra, all midgut epithelial cells (microvillar cells) show the same ultrastructural features as those connected with the digestion of blood. The only cells which differ from the digestive cells were small cells with cytoplasm that is poor in organelles, which have no contact with the midgut lumen. No markers to biologically active peptides such as hormones were used in the study, but the ultrastructure of small cells in $P$. geometra resembles that described by Punin et al. (2000). The small cells that were observed in P. geometra midgut might also play the role of midgut-regenerative cells, which in many invertebrates are known as midgut stem cells and are responsible for midgut renewal (Nardi et al. 2010; Rost-Roszkowska et al. 2010a, b). However, mitotic divisions of those cells were not observed.

Haematophagous invertebrates (e.g., mites, ticks, Anoplurans, or Mallophagans) gather blood in blind sacs formed by the foregut or the midgut (Wigglesworth 1972; Jenkins et al. 2002). The epithelium of those digestive regions synthesizes the substances which prevent the blood from coagulating. Such substances may also be produced by symbiotic bacteria observed in the cytoplasm of the digestive epithelium. During digestion, the blood generates many molecules which might be toxic for the entire organism (Taketani 2005). Therefore, different mechanisms enable neutralization of these toxic molecules (Okuda et al. 2005, 2007; Graça-Souza et al. 2006). Haem molecules generate the synthesis of reactive oxygen species which cause the disruption of cell membranes (Dunkov et al. 2002). As a result, iron and oxygen accumulate in structures called haemoxisomes, which were observed for example in haematophagous Hemiptera (Silva et al. 2006) or spherocrystals (Azevedo et al. 2009). They are membranous vesicles which possess electron-dense material and are surrounded by cisterns of rough endoplasmic reticulum. Haemoxisomes play a role in the detoxification of intracellular haem (Silva et al. 2006). Structures resembling hemipteran haemoxisomes have also been described in haematophagous arachnids, where the products related to the digestion of blood are enclosed in endosomes in which they undergo intracellular digestion (Tarnowki and Coons 1989; Filimonova 2008). During haem decomposition, molecules of insoluble crystalline haemozoin are formed and they accumulate in the cytoplasm of the midgut epithelium as the crystalline spherites (Oliveira et al. 2000). The iron resulting from the digestion of haem is bound with the molecules of ferritin produced by the crop or midgut epithelial cells (Dunkov et al. 2002), although it may also be gathered in the cytoplasm as residual bodies (Tarnowki and Coons 1989). An increase in the accumulation of electron-dense granules with iron was observed in G. complanata by Bradbury (1955). In P. geometra, numerous vesicles with an electron-dense content were observed in the cytoplasm of midgut cells. Because they occurred in the midgut epithelium of the juvenile nonfeeding specimens, it can be concluded that they are not responsible for the neutralization of the products related to the digestion of haem. The content of such vesicles increases in electron density after feeding, so it is highly probable that they possess digestive enzymes which accumulated before the feeding period. However, the process of exocytosis, which might cause the release of such enzymes into the midgut lumen, was not observed in $P$. geometra. Therefore, it may be concluded that the products related to the digestion of blood accumulate inside those vesicles and eventually undergo intracellular digestion, as has been described in blood-feeding arachnids (Ludwig and Alberti 1992; Filimonova 2008).

In blood-feeding insects, an additional barrier against the passage of the blood meal into the hemocoel is the appearance of septate junctions as occluding junctions (Lane 1982). This isolation is not complete because some molecules such as antibodies from the blood meal are able to cross the epithelium of the gut into the hemocoel (Minoura et al. 1985; Ben-Yakir et al. 1986). In $P$. geometra, zonula adherens junctions appear together with septate junctions, which must be an additional barrier for products related to the digestion of blood.

In haematophagous insects, the midgut epithelium is separated from the midgut lumen by the perimicrovillar membrane or the peritrophic membrane, which is a system composed of extracellular membrane layers (Terra 1988, 1990; Pascoa et al. 2002; Albuquerque-Cunha et al. 2004). The perimicrovillar or peritrophic membrane in haematophagous insects is responsible for binding haem, which prevents its direct contact with the midgut epithelium. It also protects the midgut epithelium against any invasion of pathogens. To date, perimicrovillar or peritrophic membranes have not been described in Hirudinea. However, in several adult specimens of $P$. geometra, a thin membranous structure between the gut contents and the apical surface of the midgut epithelium has been observed. Because this structure did not occur in juvenile specimens, it may be concluded that it is formed after the feeding.

Among Hirudinea, representatives of Rhynchobdellida possess a bacterial symbiont-containing organ (mycetome), whereas species belonging to Arhynchobdellida lack a mycetome (Buchner 1965; Sawyer 1986; Fernádez et al. 1992). The major functions of the symbionts living in the digestive tract of leeches are connected with digestion of blood meal, protection against any invasion of pathogens, and providing nutrients such as amino acids and vitamins (Graf et al. 2006).

In rhynchobdellid leeches, a mycetome is a large organ opening into the esophageal lumen and formed by large cells that are called mycetocytes (Buchner 1965; 
Sawyer 1986; Fernádez et al. 1992; Siddall et al. 2004; Perkins et al. 2005; Graf et al. 2006). Three morphotypes of mycetome have been described in Glossiphoniidae, which belong to Rhynchobdellida: (1) the large organ which surrounds the esophagus lumen, (2) a pair of pearshaped sacs, and (3) two pairs of bulbous diverticles attached to the esophagus via narrow ducts (Sawyer 1986; Perkins et al. 2005). In Arhynchobdellida, symbiotic bacteria gather in the cytoplasm of the midgut epithelium cells. In P. geometra (Rhynchobdellida), the mycetome slightly differs from those described in glossiphoniids; it is formed by two large oval diverticles opening into the esophageal lumen via short ducts (Johansson 1896; Badham 1916; Jaschke 1933). Despite the fact that the microorganisms accumulate in the lumen of such an organ, they have also been observed in the midgut epithelial cells (esophagus, crop, and intestine). Microorganisms probably enter the cytoplasm of those cells from the digestive system lumen, what might be connected with their ability to migrate through the digestive system lumen (Worthen et al. 2006). In P. geometra, sparsely distributed microorganisms have been observed in the cytoplasm of the digestive cells in the intestine, while many more of them accumulate in the esophagus and crop cells. Microorganisms were observed in both the fed adult and unfed juvenile specimens of $P$. geometra. This observation strongly suggests that in the analyzed species vertical transmission from parent to offspring occurs. How microorganisms are inherited is unknown; however, studies devoted to the oogenesis and structure of the reproductive system of several piscicolid leeches have not confirmed the presence of any bacteria in oocyte cytoplasm (Światek et al. 2007; Spałek-Wołczyńska et al. 2008).

\section{Conlusions}

Our studies show that: (1) the endodermal portion (midgut) of the digestive system is composed of four regions: the esophagus, the crop, the posterior crop caecum, and the intestine; (2) the midgut epithelium is composed of two kinds of cells: digestive and small cells of unknown function; (3) microorganisms are present both within the mycetome lumen and in midgut cell's cytoplasm; and (4) the comparison of the ultrastructure of midgut epithelium in juvenile and adult specimens suggests that electron-dense granules observed within the apical part of digestive cells take part in enzyme accumulation.

Conflict of interest The authors declare that they have no conflict of interest.
Open Access This article is distributed under the terms of the Creative Commons Attribution Noncommercial License which permits any noncommercial use, distribution, and reproduction in any medium, provided the original author(s) and source are credited.

\section{References}

Albuquerque-Cunha JM, Mello CB, Garcia ES, Azambuja P, de Souza W, Gonzalez MS, Nogueira NFS (2004) Effect of blood components, abdominal distension, and ecdysone therapy on the ultrastructural organization of posterior midgut epithelial cells and perimicrovillar membranes in Rhodnius prolixus. Mem Inst Oswaldo Cruz Rio de Janeiro 99(8):815-822

Arslan N, Emiroğlu Ö (2011) First record of parasitic AnnelidaHirudinea (Piscicola geometra Linnaeus, 1761) on Carassius gibelio (Bloch, 1782) in Lake Uluabat (Turkey). Kafkas Univ Vet Fak Derg 17(1):131-133

Azevedo DO, Neves CA, dos Santos MJR, Gonçalves TCM, Zanuncio JC, Serrão JE (2009) Notes on midgut ultrastructure of Cimex hemipterus (Hemiptera: Cimicidae). J Med Entomol $46: 435-441$

Badham C (1916) On an Ichthyobdellid parasitic on the Australian Sand Whiting (Sillago ciliata). Q J Microsc Sci 62:1-41

Baumann P (2005) Biology of bacteriocyte-associated endosymbionts of plant sup-sucking insects. Annu Rev Microbiol 59:155-189

Ben-Yakir D, Fox JC, Homer JT, Barker RW (1986) Quantitative studies of host immunoglobulin $\mathrm{G}$ passage into the hemocoel of the ticks Amblyomma americanum and Dermacentor variabilis. In: Sauer JR, Hair JA (eds) Morphology, physiology, and behavioral biology of ticks. Ellis Horwood, Chichester, pp 329341

Bielecki A (1997) Fish leeches of Poland in relation to the Paleartic piscicolines (Hirudinea: Piscicolidae: Piscicolinae). Genus 8 (2):223-375

Billingsley PF (1988) Morphometric analysis of Rhodnius prolixus (Hemiptera: Reduviidae) midgut cells during blood digestion. Tissue Cell 20:291-301

Bradbury S (1955) A cytological study of the metabolism of iron in the leech, Glossiphonia complanata. Ouart J Micr Sci 96:169172

Buchner P (1965) Endosymbiosis of animals with plant microorganisms. Wiley, New York

Dunkov BC, Georgieva T, Yoshiga T, Hall M, Law JH (2002) Aedes aegypti ferritin heavy chain homologue: feeding of iron or blood influences message levels, lengths and subunit abundance. J Insect Sci 2:7

Fernádez J, Tellez V, Olea N (1992) Hirudinea. In: Harrison FW, Gardiner SL (eds) Microscopic anatomy of invertebrates, vol. 7. Annelida. Wiley, New York, pp 323-394

Filimonova S (2008) The fine structure of the midgut in the mite Anystis baccarum (L.) (Acari, Actinedida: Anystidae). Arthropod Struct Dev 37:299-309

Graça-Souza AV, Maya-Monteiro C, Paiva-Silva GO, Braz GR, Paes MC, Sorgine MH, Oliveira MF, Oliveira PL (2006) Adaptations against haeme toxicity in blood-feeding arthropods. Insect Biochem Mol Biol 36:322-335

Graf J, Kikuchi Y, Rio RVM (2006) Leeches and their microbiota: naturally simple symbiosis models. Trends Microbiol 14(8):365371

Hammersen F, Pokahr A (1972a) Elektronenmikroskopische Untersuchungen zur Epithelstruktur im Magen-Darmkanal von Hirudo medicinalis L. I. Mitteilung: Das Epithel der Divertikel. Z Zellforsch Mikrosk Anat 125:378-403 
Hammersen F, Pokahr A (1972b) Elektronenmikroskopische Untersuchungen zur Epithelstruktur im Magen-Darmkanal von Hirudo medicinalis L. I. Mitteilung: Das Epithel des Enddarmes. Z Zellforsch Mikrosk Anat 125:532-552

Jamieson BGM (1981) The ultrastructure of the Oligochaeta. Academic Press, London

Jamieson BGM (1992) Oligochaeta. In: Harrison FW, Gardiner SL (eds) Microscopic anatomy of invertebrates. Vol. 7 Annelida. Wiley, New York, pp 217-322

Jaschke W (1933) Beiträge zur Kenntnis der symhiontischen Einrichtuiigen bei Hirudineen und Ixodiden. Z Parasitenkd 5:515-541

Jenkins CD, Ward ME, Turnipseed M, Osterberg J, van Dover CL (2002) The digestive system of the hydrothermal vent polychaete Galapagomystides aristata (Phyllodocidae): evidence for hematophagy? Env Biol 121:243-254

Johansson L (1896) Bidrag till Kiinnedomen om Sveriges Ichthyobdellider. Upsala

Lane N (1982) Insect intercellular junctions: their structure and development. In: King R, Akai $\mathrm{H}$ (eds) Insect ultrastructure, vol 1. Plenum, New York, pp 402-433

Ludwig M, Alberti G (1992) Fine structure of the midgut of the Prokoenenia wheeleri (Arachnida: Palpigradi). Zool Beitr 34:127-134

Minoura H, Chinzei Y, Kitamura S (1985) Ornithodoros moubata: host immunoglobulin $G$ in tick hemolymph. Exp Parasitol 60:355-363

Nakabachi A, Ishikawa H (1999) Provision of riboflavin to the host aphid, Acyrthosiphon pisum, by endosymbiotic bacteria, Buchnera. J Insect Physiol 45:1-6

Nardi JB, Bee ChM, Miller LA (2010) Stem cells of the beetle midgut epithelium. J Insect Physiol 56:296-303

Okuda K, Caroci A, Ribolla P, Marinotti O, de Bianchi AG, Bijovsky AT (2005) Morphological and enzymatic analysis of the midgut of Anopheles darlingi during blood digestion. J Insect Physiol 51:769-776

Okuda K, de Almeida F, Mortara RA, Krieger H, Marinotti O, Bijovsky AT (2007) Cell death and regeneration in the midgut of the mosquito, Culex quinquefasciatus. J Insect Physiol 53:13071315

Oliveira MF, Silva JR, Dansa-Petretski M, de Souza W, Braga CM, Masuda H, Oliveira PL (2000) Haemozoin formation in the midgut of the blood-sucking insect Rhodnius prolixus. FEBS Lett 477:95-98

Pascoa V, Oliveira PL, Dansa-Petretski M, Silva JR, Alvarenga PH, Jacobs-Lorena M, Lemos FJ (2002) Aedes aegypti peritrophic matrix and its interaction with haeme during blood digestion. Insect Biochem Mol Biol 32:517-523

Perkins SL, Budinoff RB, Siddall ME (2005) New gammaproteobacteria associated with blood-feeding leeches and a broad phylogenetic analysis of leech endosymbionts. Appl Environ Microbiol 71:5219-5224

Punin MYu, Lukyanova EL (1984) Organization of the epithelium of the midgut in errant polychaete Nereis virens. II. Basal cells. Tsitologiya 26:188-195
Punin MYu, Kazakov VK, Mkrtchyan LG (2000) Immunohistochemical detection of regulatory cells in the digestive system of leeches. J Evol Biochem Physiol 36:190-197

Rost-Roszkowska M, Jansta P, Vilimova J (2010a) Fine structure of the midgut epithelium in two Archaeognatha, Lepismachilis notata and Machilis hrabei (Insecta) in relation to its degeneration and regeneration. Protoplasma 247:91-101

Rost-Roszkowska M, Vilimova J, Chajec $Ł$ (2010b) Fine structure of the midgut epithelium and midgut stem cells differentiation in Atelura formicaria (Insecta, Zygentoma, Ateluridae). Zool Stud 49:10-18

Rost-Roszkowska MM, Poprawa I, Wojtowicz M, Kaczmarek $Ł$ (2011) Ultrastructural changes of the midgut epithelium in Isohypsibius granulifer granulifer Thulin, 1928 (Tardigrada: Eutardigrada) during oogenesis. Protoplasma 248(2):405-414

Saulnier-Michel C (1992) Polychaeta: Digestive system. In: Harrison FW, Gardiner SL (eds) Microscopic anatomy of invertebrates. Vol. 7. Annelida. Wiley, New York, pp 53-69

Sawyer RT (1986) Leech biology and behavior. Clarendon Press, Oxford

Siddall ME, Perkins SL, Desser SS (2004) Leech mycetome endosymbionts are a new lineage of alphaproteobacteria related to the Rhizobiaceae. Mol Phyl Evo 30:178-186

Siddall ME, Bely AE, Borda E (2006) Hirudinida. In: Rouse G, Pliejel F (eds) Reproductive biology and phylogeny of Annelida. Enfield, New Hampshire

Silva JR, Gomes-Silva L, Lins UC, Nogueira NFS, Petretski MD (2006) The haemoxisome: a heme-iron containing structure in the Rhodnius prolixus midgut cells. J Insect Physiol 52:542-550

Spałek-Wołczyńska A, Klag J, Bielecki A, Świątek P (2008) Oogenesis in four species of Piscicola (Hirudinea, Rhynchobdellida). J Morphol 269:18-28

Światek P, Bielecki A, Klag J (2007) Structure of the vector tissue in piscicolid leeches (Annelida, Hirudinea, Rhynchobdellida, Piscicolidae). J Morphol 268:64-73

Świątek P, Urbisz AZ, Strużyński W, Płachno BJ, Bielecki A, Cios S, Salonen E, Klag J (2011) Ovary architecture of two branchiobdellid species and Acanthobdella peledina (Annelida, Clitellata). Zool. Anz. doi:10.1016/j.jcz.2011.08.001.

Taketani S (2005) Acquisition, mobilization and utilization of cellular iron and heme: endless findings and growing evidence of tight regulation. Tohoku J Exp Med 205:297-318

Tarnowki BI, Coons LB (1989) Ultrastructure of the midgut and blood meal digestion in the adult tick Dermacentor variabilis. Exp Appl Acarol 6:263-289

Terra WR (1988) Physiology and biochemistry of insect digestion: an evolutionary perspective. Braz J Med Biol Res 21:675-734

Terra WR (1990) Evolution of digestive system of insects. Annu Rev Entomol 35:181-200

Wigglesworth VB (1972) The principles of insect physiology, 7th edn. Chapman and Hall, London

Worthen P, Gode CJ, Graf J (2006) Culture-independent characterization of the digestive-tract microbiota of the medicinal leech reveals a tripartite symbiosis. Appl Environ Microbiol 72 (7):4775-4781 